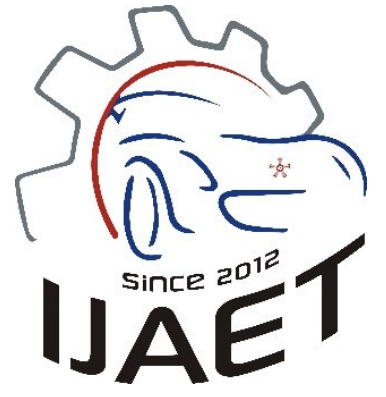

e-ISSN: 2146 - 9067

International Journal of Automotive

Engineering and Technologies

journal homepage:

https://dergipark.org.tr/en/pub/ijaet

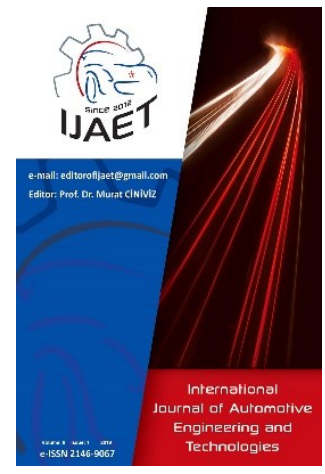

Original Research Article

\title{
Investigation on effects of the exhaust emission characteristics of diesel engine fuelled with mahua oil methyl esters and its blends with diesel
}

\author{
M. Sivakumar ${ }^{1 *}$, N. Shanmuga Sundaram², R. Rameshkumar ${ }^{1}$ \\ ${ }^{1}$ Department of Automobile Engineering, K.S.R. College of Engineering, Tiruchengode - 637215, India \\ ${ }^{2}$ Department of Mechanical Engineering, SVS College of Engineering, Coimbatore - 642109, India
}

\section{ARTICLE INFO}

* Corresponding author kpmshiva@gmail.com

Received: July 15,2019

Accepted: Dec 20, 2019

Published by Editorial Board Members of IJAET

(C) This article is distributed by Turk Journal Park System under the CC 4.0 terms and conditions.

\begin{abstract}
Diesel engines are deliberately known for environmental pollution caused by exhaust emissions and are liable for many health issues further more. Emissions of diesel exhaust might lead to cancer, irritate the eyes, affects the nose, throat and lungs. Biodiesel is an eco-friendly and typical alternative fuel which is produced from vegetable oils through transesterification technique. Biodiesel has its own several advantages than the conventional diesel says decreased in carbon monoxide $(\mathrm{CO})$, unburnt hydrocarbon (HC) and particle matter (PM) emissions, and having fuel properties which are similar to conventional diesel for its easier use in diesel engines. The outcomes demonstrated that the production of lesser $\mathrm{CO}$ and $\mathrm{HC}$ emission using biodiesel. Nevertheless, a minor increment in $\mathrm{NO}_{\mathrm{x}}$ emission was noticed for mahua oil methyl ester blends. Brake Specific Fuel Consumption (BSFC) for methyl ester blends was raised as compared to diesel. The combustion analysis exhibited a significant rise in combustion pressure and heat release rate with smaller ignition delay and extended combustion period. From the investigation, it could be said that the effects of mahua oil methyl esters and its blends on diesel engine when compared to conventional diesel ultimately minimizes the health effects of biodiesel exhaust exposure.
\end{abstract}

Keywords: Mahua oil methyl esters; Emission Characteristics; Diesel Exhaust

\section{Introduction}

Air pollution is now completely recognized as significant public health problem, liable for a growing with variety of health effects associated with air pollution have been well documented from the studies conducted in several regions of the world. Diesel engines have great utilization in comparison to gasoline engines attributable to their low operating costs, high durability and reliability. They have a significant impact upon environmental pollution problem worldwide. Especially, diesel exhaust contains higher amount of particulate matter and $\mathrm{NO}_{\mathrm{x}}$ emissions which can be accountable of extreme environmental and health problems [1]. The diesel combustion in an uncontrolled manner releases harmful particulate matter, increased $\mathrm{NO}_{\mathrm{x}}$ and various cancer-causing substances. 
Due to speedy increase of motorized vehicles and really restricted use of emission control technologies, transport emerges as the major source of urban air pollution, which is a crucial public health problem in many urban communities of developing countries like India. In developing countries, air pollution accounts for thousands of excess deaths and loses in productivity and billions of dollars in medical expenses annually [2]. The World Health Organization (WHO) estimated that approximately 2.4 million people die every year due to air pollution [3]. Of the toxins considered, carbon monoxide $(\mathrm{CO})$ has critical impact on asthma for children of ages 1 - 18: when compared with the 1992 pollution levels, there could be a $5-14 \%$ increase in asthma admissions for the 1998 pollution levels. It is significant to represent for these endogenous responses when measuring the impact of pollution on health [4]. In addition, it will cause severe coughing, headaches and nausea. Diesel exhaust causes inflammation in the lungs which could worsen chronic respiratory symptoms and increase the frequency or intensity of asthma and could increase the risk of heart problems and premature death. Studies have shown that exposure to diesel exhaust emissions cause respiratory problems and lung damage, and there are solid confirmations that diesel emissions may cause cancer in humans $[5,6]$. The feasible solution for the collective issues of energy demand and environmental pollution is replacement of fossil fuels with renewable fuel with reduced emissions [7]. A multi-sectional methodology, participating relevant bodies like transport, housing, industry, is required to develop and viably execute long-term policies and measures to diminish air pollution and also the associated risk to human health. Biodiesel is a realistic alternative to mineral diesel fuel; it is a fuel made up of renewable resources and has lower exhaust emissions than mineral diesel. When contrasted with fossil fuels; biodiesel also considerably reduces the quantity of carbon dioxide being released into the surroundings by diesel engine vehicles. In addition, biodiesel is an oxygenated fuel, thus it contributes to additional complete fuel burn and significantly improves the profile of emissions of a diesel engine. The more biodiesel mixed in a blend, the substantial reductions in exhaust emissions. The literatures indicated that biodiesel will lead to $50-80 \%$ decline in carbon dioxide emissions as associated to mineral diesel $[8,9]$. One of the distinctive benefits of biodiesel is that it considerably reduces air pollutants, like sulfur oxides and carbon oxides, which are related to diesel exhaust emissions and are suspected of causing cancer and other human health problems. The combustion of mineral diesel produces several harmful emissions like $\mathrm{NO}_{\mathrm{x}}$, $\mathrm{CO}, \mathrm{CO}_{2}$, and $\mathrm{HC}$ [10]. Devan and Mahalakshmi [11] studied the performance, combustion and emission characteristics of a diesel engine on Methyl Ester of Paradise oil and its diesel blends. They have reported that significant reduction in smoke and unburned hydrocarbon emissions was found. Suryanarayanan et al. [12] investigated the performance and emission characteristics of methyl esters of various vegetable oils and compared with the mineral diesel. Saravanan et al. [13] directed the tests on a single cylinder diesel engine with mahua oil methyl ester blends. They revealed that the $\mathrm{CO}, \mathrm{HC}$ emissions for mahua ester was diminished contrasted with diesel by $26 \%$ and $20 \%$ individually. $\mathrm{NO}_{\mathrm{x}}$ was decreased by $4 \%$ for the ester contrasted to diesel. Nantha Gopal et al. [14] inspected the emission and combustion attributes of pongamia methyl ester on diesel engine. It is noticed that there was substantial decrease in $\mathrm{CO}, \mathrm{HC}$ and smoke emissions for all PME mixtures when contrasted with diesel. $\mathrm{NO}_{\mathrm{x}}$ emission for PME was marginally greater than that of diesel. Arunprasad et al. [15] researched the impact of injection timing and injection pressure on the performance and emission attributes of diesel engine with biodiesel blends. The outcomes demonstrated that decrease of $5.08 \%$ of brake specific fuel consumption (BSFC) was observed. The decline in $29.17 \%$, $53.85 \%$ and $21.95 \%$ of $\mathrm{HC}, \mathrm{CO}$ and smoke emissions was noticed and furthermore substantial rise in $\mathrm{NO}_{\mathrm{x}}$ emission at full load was noticed. Nanthagopal et al. [16] considered the impacts of including zinc oxide and titanium dioxide nanoparticles to biodiesel mixes on a diesel engine performance and emission attributes. The outcomes revealed that the engine emissions of $\mathrm{NO}_{\mathrm{x}}, \mathrm{HC}$ and $\mathrm{CO}$ were diminished considerably by $29 \%, 40 \%$ and $40 \%$ individually. There was likewise a substantial 
reduction in smoke, $\mathrm{HC}$ and $\mathrm{CO}$ emissions for higher volume proportions of biofuel excluding $\mathrm{NO}_{\mathrm{x}}$ emission. The benefit of utilizing biodiesel in India is development in agriculture and rural economy, usage of waste land and decrease in crude oil import bill. The aim of the present investigation is to examine the exhaust emission attributes of diesel engine fueled with mahua oil methyl esters and its blends with diesel.

\section{Preparation of Biodiesel and Its Blends}

Biodiesel is an alternate fuel, which incorporates a correlation with sustainable development, environmental preservation, energy conservation and management. The biodiesel is obtained from mahua oil by transesterification process. The mahua oil was chemically reacted with methanol in the presence of catalyst $(\mathrm{NaOH})$ to produce methyl esters. The mixture was heated at a temperature of $65^{\circ} \mathrm{C}$ and reaction time of 2 hours and then it was allowed to settle down under gravity. Two layers were observed after the cooling. The upper layer was identified as methyl ester and then the methyl ester was washed with warm water to remove the catalyst present in the ester. The mahua methyl ester so prepared was blend with mineral diesel in different proportions $(25 \%, 50 \%, 75 \%, 100 \%)$ by volume (B25, B50, B75 and B100) with help of a magnetic stirrer. The properties of prepared methyl esters and its blends with diesel measured as in line with ASTM are given in Table 1.

Table 1. Properties of Mahua methyl esters and its blends, diesel

\begin{tabular}{lcccccc}
\hline Properties & Unit & Diesel & Mahua methyl ester & B25 & B50 & B75 \\
\hline Density (at $15{ }^{\circ} \mathrm{C}$ & $\mathrm{kg} / \mathrm{m}^{3}$ & 821 & 872.5 & 848 & 862 & 872 \\
Kinematic viscosity $\left(\right.$ at $\left.40{ }^{\circ} \mathrm{C}\right)$ & $\mathrm{mm}^{2} / \mathrm{s}$ & 2.57 & 4.36 & 2.89 & 3.47 & 3.76 \\
Calorific value & $\mathrm{kJ} / \mathrm{kg}$ & 42960 & 36915 & 41750 & 39215 & 37425 \\
Cetane number & --- & 46 & 53 & 51.5 & 52.3 & 52.8 \\
Flash point & ${ }^{\circ} \mathrm{C}$ & 65 & 130 & 103 & 115 & 121 \\
Pour point & ${ }^{\circ} \mathrm{C}$ & -18 & 5 & -3 & 2 & 4.5 \\
\hline
\end{tabular}

Table 2. Specifications of test engine

\begin{tabular}{|c|c|}
\hline Parameters & Specification \\
\hline Model & AV1 (Kirloskar made) \\
\hline Engine type & $\begin{array}{l}\text { Vertical, Single Cylinder, Water cooled, Four stroke, } \\
\text { Direct injection, compression Ignition Engine }\end{array}$ \\
\hline Maximum power & $3.7 \mathrm{~kW}$ at $1500 \mathrm{rpm}$ \\
\hline Bore X Stroke & $80 \mathrm{~mm} \mathrm{X} 110 \mathrm{~mm}$ \\
\hline Displacement volume & $553 \mathrm{cc}$ \\
\hline Compression ratio & $16.5: 1$ \\
\hline Fuel injection timing & $23^{\circ}$ before TDC \\
\hline Injector: hole $\mathrm{X}$ diameter & $3 \times 0.25 \mathrm{~mm}$ \\
\hline Dynamometer & Eddy current dynamometer \\
\hline
\end{tabular}

\section{Experimental Setup and Procedure}

The experimental investigation was carried out on a single cylinder, four stroke, naturally aspirated, water cooled constant speed, direct injection diesel engine. The main specifications of the engine test rig are given in Table 2 and photographic view of experimental set up is shown in Figure 1. The engine was loaded by an Eddy current dynamometer through computer. The engine was operated to have a constant speed of $1500 \mathrm{rpm}$.

The engine had a typical fuel injection system. Injector was given three holes and each having an orifice diameter of $0.25 \mathrm{~mm}$. The injection pressure and the static injection timing as stated by the producer was 205 bar and $23^{\circ}$ bTDC correspondingly. The pressure sensor was used to measure the cylinder pressure. The engine speed, crank angle was measured using sensors in data-acquisition system which is connected through the computer. Air consumption was measured by means of sharp edged orifice plate and U-tube manometer.

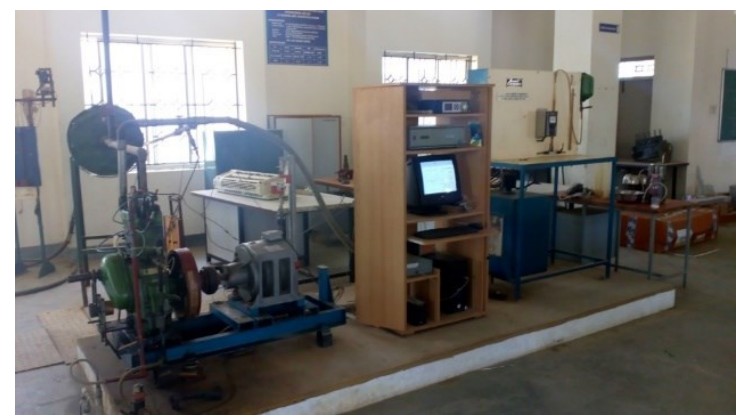

Figure 1. Photographic view of experimental set up 
Fuel consumption was measured by using burette and stop watch. Different digital thermocouples were used to measure the temperatures of various salient points. The amount of exhaust emissions like $\mathrm{CO}_{2}, \mathrm{CO}, \mathrm{HC}$ and $\mathrm{NO}_{\mathrm{x}}$ were measured using exhaust gas analyzer (Make: AVL; Model: DiGas 444). The smoke density was measured using smoke meter (Make: AVL; Model: 437). The EGR set up was installed, which recirculates the exhaust gas back into the air-intake manifold. At the completion of every test, the engine was worked with diesel under idle load at a speed of 1500 rpm for ten minutes to confirm that the engine to confirm that the engine fuel system was free from any residuals of the earlier test fuels. The engine was sufficiently warmed up for each test. The whole investigation has been run at an atmospheric temperature of $298 \mathrm{~K}$ and a relative humidity of $70 \%$. The test procedure is repeated for three times and the arithmetic mean values of these three readings were used for calculation and analysis purpose. In this present study, the biodiesel and its blends (Diesel, B25, B50, B75 and B100) were studied at different engine loads from $0 \%$ to $100 \%$ of rated engine load. Besides, investigational uncertainty has been considered in this study in order to measure the error that happens owing to the decision of technique embraced at an ambient condition. The uncertainty particulars of the instruments utilized as a part of investigation are given in Table 3. The investigational uncertainty has been learned with the aid of propagating errors method based on Taylor's theorem.

The proportion uncertainties of various physical parameters such as brake thermal efficiency, brake specific fuel consumption, and emission parameters such as smoke, $\mathrm{NO}_{\mathrm{x}}, \mathrm{HC}$ and $\mathrm{CO}$ were measured with the percentage uncertainties of various instruments. Overall uncertainties were specified by the successive equation.

Overall uncertainty $=$ Square root of $\left[(\text { Uncertainty of brake thermal efficiency })^{2}+\right.$ (Uncertainty of brake specific fuel

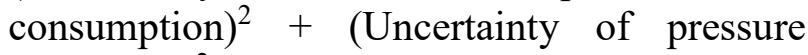

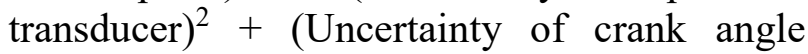
encoder $)^{2}+(\text { Uncertainty of } \mathrm{HC})^{2}+($ Uncertainty of $\mathrm{CO})^{2}+\left(\text { Uncertainty of } \mathrm{NO}_{\mathrm{x}}\right)^{2}+($ Uncertainty of smoke $)^{2}$ ]

$=$ Square root of $\left[(1.5)^{2}+(1.2)^{2}+(0.2)^{2}+(0.2)^{2}\right.$

$\left.+(0.2)^{2}+(0.2)^{2}+(0.2)^{2}+(1.0)^{2}\right]$

$= \pm 2.21$

Table 3 Uncertainty of the instruments at typical operational conditions

\begin{tabular}{lcll}
\hline \multicolumn{1}{c}{ Instrument } & Range & Accuracy & Uncertainties in \% \\
\hline Exhaust gas analyzer & \\
\hline $\mathrm{HC}(\mathrm{ppm})$ & $0-20,000$ & \pm 10 & \pm 0.2 \\
$\mathrm{NO}_{\mathrm{x}}$ & $0-5000$ & \pm 20 & \pm 0.2 \\
$\mathrm{CO}(\%)$ & $0-10$ & \pm 0.03 & \pm 0.2 \\
$\mathrm{CO}_{2}(\%)$ & $0-10$ & \pm 0.02 & \pm 1.0 \\
Smoke meter (HSU) & $0-100$ & \pm 0.2 & \pm 1.0 \\
Crank angle encoder $\left({ }^{\circ} \mathrm{CA}\right)$ & & \pm 1.0 & \pm 0.2 \\
Measuring Burette $(\mathrm{cc})$ & $0-30$ & \pm 0.25 & \pm 1.0 \\
Pressure transducer (bar) & $0-110$ & \pm 1.0 & \pm 0.2 \\
Thermocouple ( $\left({ }^{\circ} \mathrm{C}\right)$ & $0-1500$ & \pm 1.0 & \pm 0.15 \\
Speed sensor (rpm) & $0-20,000$ & \pm 10 & \pm 0.1 \\
\hline
\end{tabular}

\section{Results and Discussion}

\subsection{Brake specific fuel consumption}

BSFC is the amount of fuel provided to the engine for produce the unit power output [17]. The BSFC of any fuel relies upon the density, heat energy content and viscosity. The BSFC of biodiesel mixes diminishes with consistent increment in load. The BSFC of diesel is found to slighter than mahua methyl ester mixes at all engine loading conditions. The notable explanations for rise in BSFC for mahua oil methyl ester are inferior heating value, upper density and viscosity than diesel. The rise in BSFC with an increment in biodiesel mix can be owing to the extra fuel utilization of biodiesel by engine for keeping power output at a consistent level [18].

\subsection{Cylinder pressure}

The variations in cylinder pressure with crank angle for different test fuel blends shown in figure 3. Ignition delay is a significant constraint in the combustion process. Ignition delay period impacts the combustion phase in the engine cycle, the thermodynamic effectiveness and 
degree of premixing of fuel vapour. The ignition delay displays an inferior value even though utilizing methyl esters mixes than diesel fuel while methyl ester has upper viscosity and lesser volatility properties [19]. The cylinder pressure for methyl ester mixes is marginally greater than that of diesel. The peak cylinder pressure relies chiefly on the initial stage combustion rate which is affected by the fuel taking part in the uncontrolled combustion stage. The peak cylinder pressure was noticed for methyl ester mixes.

The cause for the higher cylinder pressure is combustion enhancement which outcomes from its upper cetane number and oxygen content of the methyl ester mixes than diesel. The oxygen content of methyl ester blends increases the oxidation rate and supports the finishing of the initial stage of diffusion combustion process in the fuel rich zones and outcomes in upper cylinder pressure utilizing methyl ester blends [20].

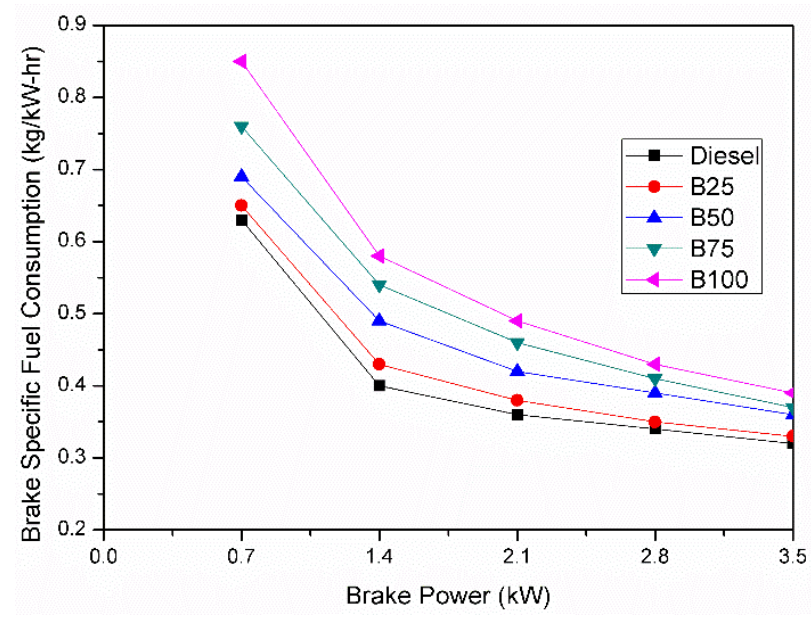

Figure 2: Variation of Brake specific fuel consumption with Brake power

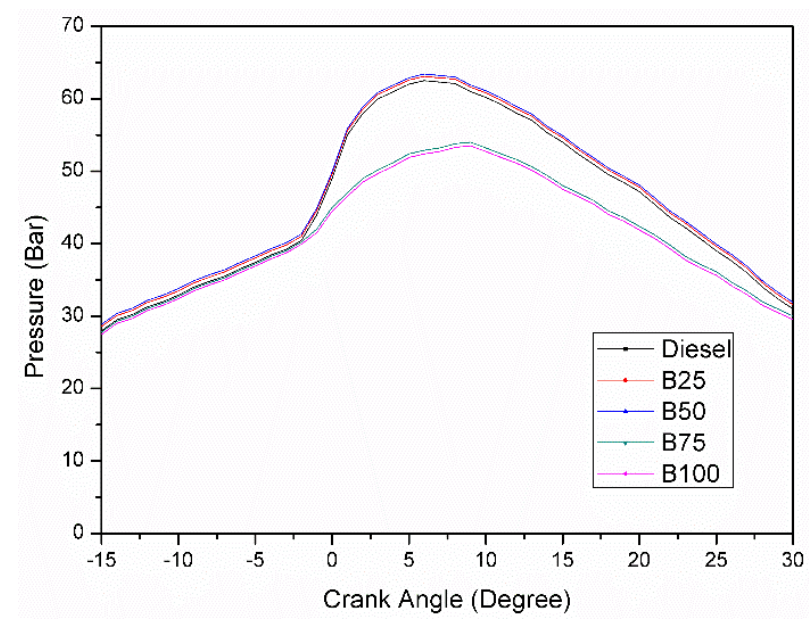

Figure 3: Variation of Cylinder Pressure with Crank angle

\subsection{Heat release rate}

The heat release rate gives the combustion process initiation and the quantity of fuel burnt in the premixed combustion stage [21]. Figure 4 shows the variations in heat release rate with crank angle for different test fuel blends. The heat release rate curve illustrations a lessening in heat release rate in the premixed combustion stage at the initial phases for methyl ester blends. It is owing to the shorter ignition delay and inferior heating value of methyl ester blends. The upper heat release rates for methyl ester blends could be owing to oxygen content of the methyl ester mixes which enhance the oxidation of fuel particles that prompts to the finishing of initial phase of diffusion combustion, consequently raising the heat release rate [22].

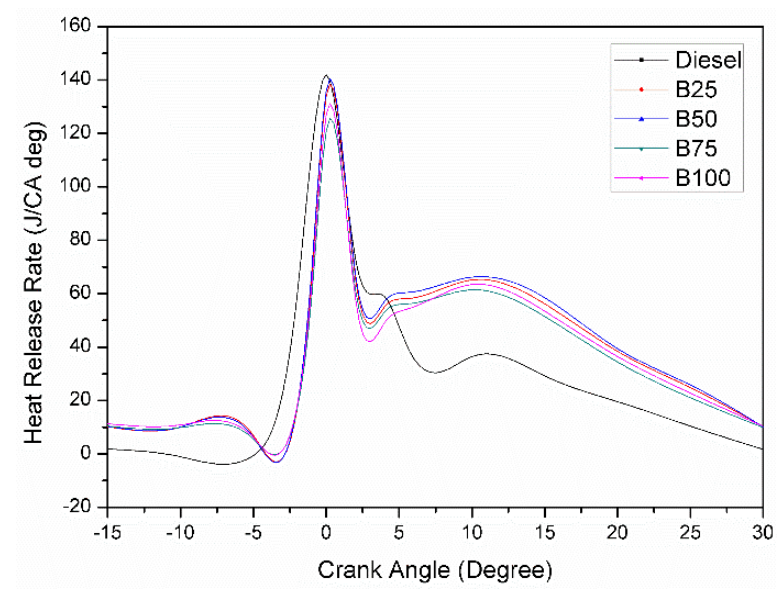

Figure 4: Variation of Heat release rate with Crank angle

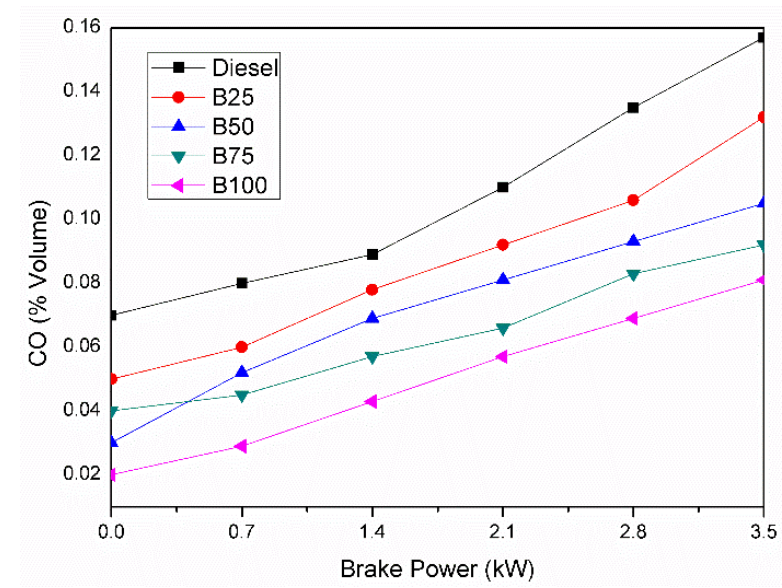

Figure 5: Variation of $\mathrm{CO}$ emission with Brake Power

\subsection{Carbon monoxide emission}

The variation of carbon monoxide (CO) emission with brake power for methyl ester blends and diesel is presented in figure 5. It is observed that the $\mathrm{CO}$ emissions for mahua methyl ester and its blends are lesser than that of 
mineral diesel fuel. These lower CO emissions of mahua methyl ester blends could also be because of their additional complete oxidation as compared to diesel. The establishment of CO emissions is owing to unfinished combustion process and the inaccessibility of oxygen in the combustion chamber. Some of the CO formed during combustion of methyl ester blends might have converted into $\mathrm{CO}_{2}$ by taking up the more oxygen molecule present in the methyl esters structure and thus reduces $\mathrm{CO}$ formation [23]. Therefore, the combustion is enhanced with the extra number of oxygen particles and complete combustion process. This reason is recognized to be main purpose for lessening of $\mathrm{CO}$ emission using methyl ester mixes [24]. The reduction in the concentration of CO emission is about $40 \%$ compared to diesel. The same trends were also observed in other studies $[25,26]$.

\subsection{Carbon dioxide emission}

Figure 6 depicts the carbon dioxide $\left(\mathrm{CO}_{2}\right)$ emission with brake power. The $\mathrm{CO}_{2}$ emission plays a main part in global warming. The $\mathrm{CO}_{2}$ emissions from a diesel engine show how efficiently the fuel is burnt inside the combustion chamber. It is seen that $\mathrm{CO}_{2}$ increases with increasing load for all the blends of methyl esters. This is due to the occurrence of oxygen. In the case of methyl esters, additional oxygen present helps combustion compared to diesel. Hence, $\mathrm{CO}_{2}$ emission in the exhaust is also more than that of diesel. Similar conclusions were stated by Ramadhas et al. [27] when the engine was tested with methyl ester of rubber seed oil.

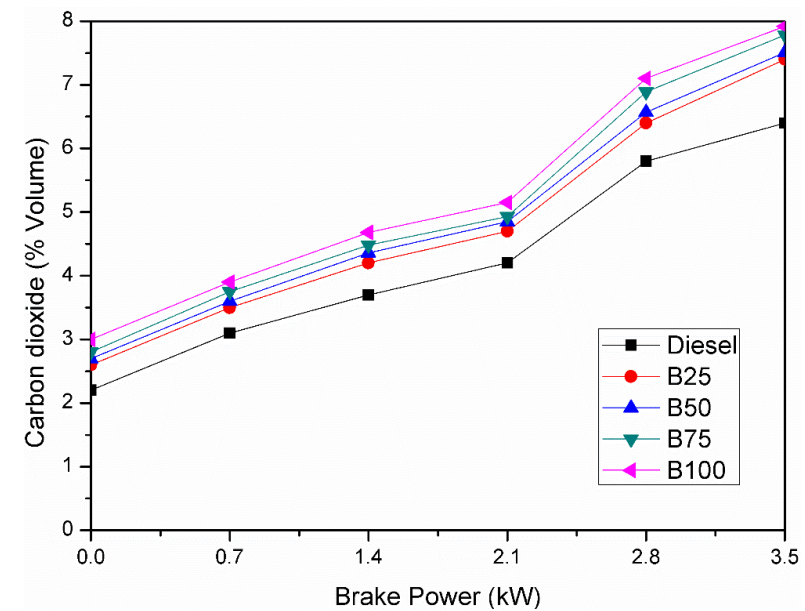

Figure 6: Variation of $\mathrm{CO}_{2}$ emission with Brake Power

\subsection{Hydrocarbons emission}

The variation of hydrocarbon (HC) emission with brake power for methyl ester blends and diesel is presented in Figure 7. HC emission is one of the organic mixtures and the outcomes of incomplete combustion process. There is a decrease in $\mathrm{HC}$ emission with the mahua methyl esters and its blends when compared to mineral diesel. The reduction in concentration of $\mathrm{HC}$ is almost 35\% lesser compared to diesel. The diminution in $\mathrm{HC}$ emission utilizing mahua methyl esters mixes is mostly owing to the oxygen content of the methyl ester which outcomes in a cleaner and complete combustion [28].

The upper cetane number of mahua methyl ester reduces the ignition delay period and motivates the decrease in HC emission [29]. The HC emission increases with increase in engine load and decreases with increase in percentage of methyl ester in blend. The results were almost in line with the other reports $[30,31]$.

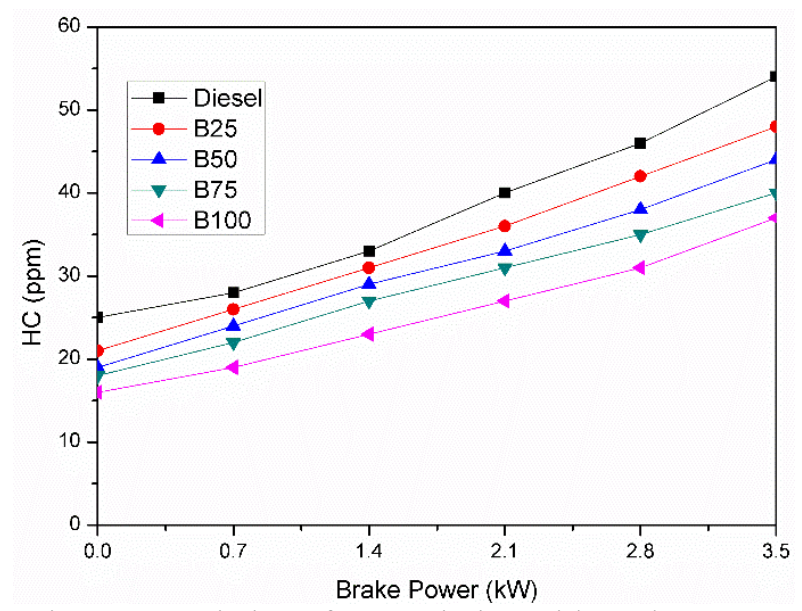

Figure 7: Variation of HC emission with Brake Power

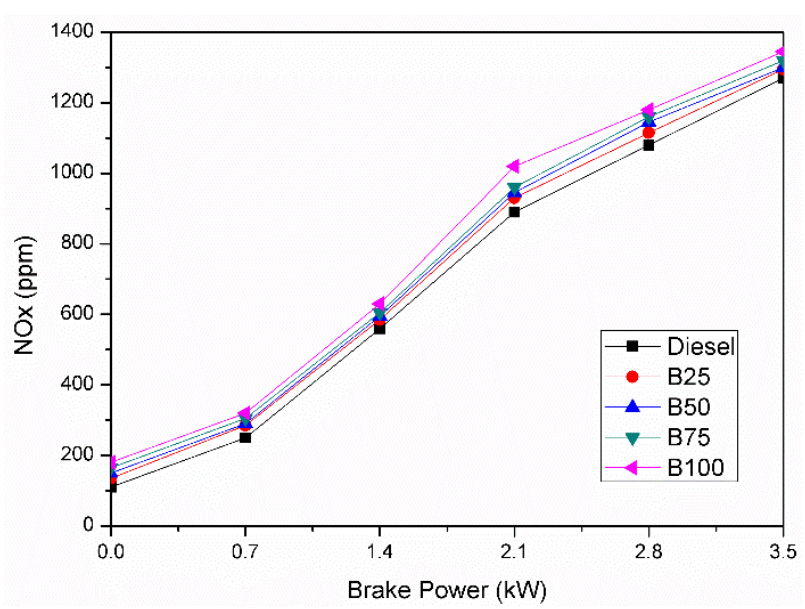

Figure 8: Variation of $\mathrm{NO}_{\mathrm{x}}$ emission with Brake Power

\section{7. $\mathrm{NO}_{\mathrm{x}}$ emission}

The variation of oxides of nitrogen $\left(\mathrm{NO}_{\mathrm{x}}\right)$ emission with brake power for methyl ester blends and diesel is presented in figure 8. It 
could be seen that the increase in proportions of mahua methyl ester with the blends found to be increase in $\mathrm{NO}_{\mathrm{x}}$ emissions slightly when compared with mineral diesel. $\mathrm{NO}_{\mathrm{x}}$ emissions are sensitive to adiabatic flame temperature, oxygen content and spray characteristics [32, 33]. In general, the concentration of nitrogen oxides varies linearly with engine load. The upper $\mathrm{NO}_{\mathrm{x}}$ emission could be ascribed to the greater oxygen content of the methyl ester which prompts to a complete combustion and upper combustion temperature, thereby producing a rise in $\mathrm{NO}_{\mathrm{x}}$ emission [34]. The $\mathrm{NO}_{\mathrm{x}}$ emission is higher for methyl ester and its blends, but methyl ester does not create any harmful effects to human health. This is in line with other reports $[35,36]$.

\subsection{Oxygen concentration}

Figure 9 illustrates the variation of oxygen percentage with brake power for methyl ester blends and diesel. The proportion of oxygen present in the methyl esters is greater. This oxygen along with oxygen from intake air takes part in the combustion then the excess oxygen is exhausted. The oxygen proportion in the exhaust gas for the neat methyl ester blends is very low which shows that more amount of oxygen contributes in the combustion process to release heat energy. There is a minor increment in oxygen proportion with methyl esters and diesel blends. The rise of oxygen with diesel fuel operation is due to lesser combustion as compared to neat methyl esters.

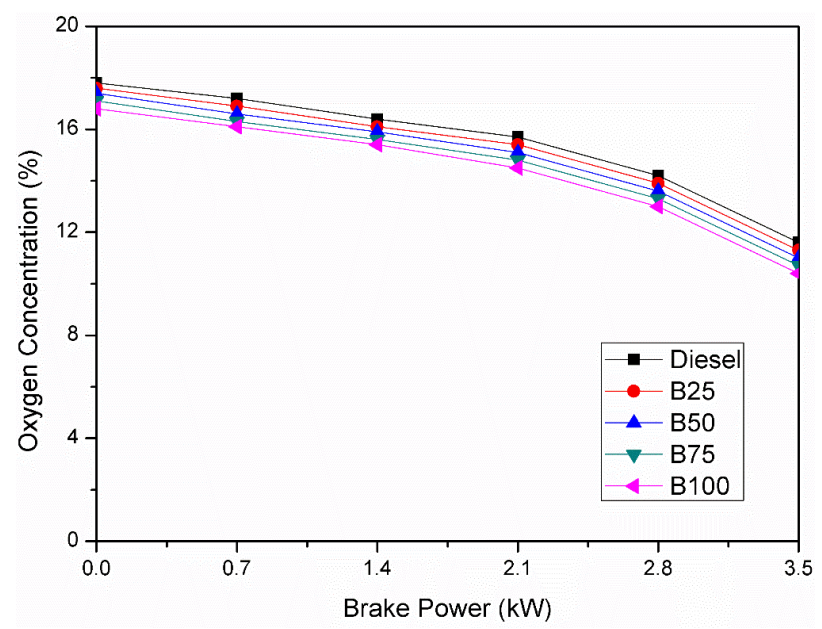

Figure 9: Variation of $\mathrm{O}_{2}$ percentage with Brake Power

\section{Conclusion}

Based on the results of this study, the following detailed conclusions were drawn:
- Mahua methyl esters and its blends produced from non-edible oils are significantly less toxic to human health than mineral diesel. When using methyl ester in diesel engine applications, the pollutants of methyl ester from the engine are reduced drastically, which in turn reduces the loss of productivity and also medical expenses.

- $\quad$ For the engine performance, owing to the inferior heating of mahua methyl ester, the BSFC improved with incrementing methyl ester percentages in diesel fuel. Cylinder pressure incremented with smaller ignition delay owing to a greater cetane number of mahua methyl esters. It appears that the fuel-bound oxygen of methyl esters enhanced the diffusion combustion rate which outcomes in healthier combustion phasing. The heat release rate marginally improved for methyl ester blends than diesel.

- $\quad$ From the environmental point view, the emission of carbon monoxide (CO) and unburnt hydrocarbon $(\mathrm{HC})$ were lesser except $\mathrm{NO}_{\mathrm{x}}$ when compared with diesel. These exhaust pollutants will make harmful effects on human health and as well as on environment also.

- Utilization of methyl ester in compression ignition engines reduces greenhouse gas (GHG) emission as a result of non-edible oil production consumes part of carbon dioxide, which is produced during combustion of these fuels in the engines.

- $\quad$ Blends of diesel and methyl ester could also be helpful in reducing harmful gases from the engine, which in turn helps to meet out the stringent automotive emission norms and to prevent the harmful effects of pollutant emissions on environment and also on human health.

For the complete elimination of exhaust emissions from diesel engines, further researches and studies should be carried out intensely.

\section{References}

1. Prasad R, Bella VR, “A review on diesel soot emissions, its effect and control, Bull chem React Eng Catal", 5:2, 69 - 86, 2010.

2. Sivaloganathan S, "Case report: death from diesel fumes", Journal of Clinical Forensic Medicine, 5, 138 - 139, 1998.

3. World Health Organization (WHO), 
Estimated deaths \& DALYs attribute to selected environmental risk factors, by WHO member state, Department of Public Health and Environment, 2007.

4. Neidell M J, "Air pollution, health, and socio-economic status: the effect of outdoor air quality on childhood asthma", Journal of Health Economics, 23, 1209 - 1236, 2004.

5. Lewtas J, "Air pollution combustion emissions: Characterization of causative agents and mechanism associated with cancer, reproductive, and cardiovascular effects", Mutation Research: Reviews in Mutation Research, 636, 95 - 133, 2007.

6. Burr M, Gregory C, "Vehicular exhaust", Encylopedia Environment and Health, 49, 645-653, 2011.

7. Suresh kumar K, Velraj R, "Performance and emission characteristics study of the use of environment friendly pongamia pinnata methyl ester in C.I. engines", Journal Energy and Environment, 5, 60-70, 2007.

8. Carraretto C, Macor A, Mirandola A, Stoppato A, "Biodiesel as alternative fuel: experimental analysis and energetic evaluations", Energy, 29, 2195 - 2211, 2004.

9. Lapuerta M, Herreros J M, Lyons L L, Garcia-Contreras R, Brice Y, "Effect of the alcohol type used in the production of waste cooking oil biodiesel on diesel engine performance and emissions", Fuel, 87, 3161 3169, 2008.

10. Saravanan N, Nagarajan G, Kalaiselvan K M, Dhanasekaran C, "An experimental investigation on hydrogen as a dual fuel for diesel engine system with exhaust gas recirculation technique", Journal of Renewable Energy, 33, 422 - 427, 2008.

11. Devan P K, Mahalakshmi N V, "Utilization of unattended methyl ester of paradise oil as fuel in diesel engine", Fuel, 88:10, 1828 - 1833, 2009.

12. Suryanarayanan S, Janakrishan V, Rao G, Sampath S, "Comparative study of the performance and emission characteristics of biodiesels from different vegetable oils with diesel", SAE Technical paper, No. 011581, 2008.

13. Saravanan N, Nagarajan G, Sukumar Puhan, "Experimental investigation on a DI diesel engine fuelled with madhuca indica ester and diesel blend", Biomass and Bioenergy, 34,
$838-843,2010$.

14. Nantha Gopal K, Thundil Karupparaj R, "Effect of pongamia biodiesel on emission and combustion characteristics of DI compression ignition engine", Ain Shams Engineering Journal, 6:1, 297 - 305, 2015.

15. Arunprasad S, Balusamy T, "Experimental investigation on the performance and emission characteristics of a diesel engine by varying the injection pressure and injection timing using mixed biodiesel", International Journal of Green Energy, 15 (6), 376 - 384, 2018.

16. Nanthagopal K, Ashok B, Tamilarasu A, Johny A, Mohan A, "Influence on the effect of zinc oxide and titanium dioxide nanoparticles as an additive with calophyllum inophyllum methyl ester in a CI engine", Energy Conversion and Management, 146, 8-19, 2017.

17. Sathiyamoorthi R, Sankaranarayanan, "The effects of using ethanol as additive on the combustion and emissions of a direct injection diesel engine fuelled with neat lemongrass oildiesel fuel blend", Renewable Energy, 101, 747 $-756,2017$.

18. Sathiyamoorthi R, Sankaranarayanan, "Effects of antioxidant additives on the performance and emission characteristics of a DICI engine using neat lemongrass oil-diesel blend", Fuel, 174, 89 - 96, 2016.

19. Wei Jet Thoo, Arman Kevric, Hoon Kiat $\mathrm{Ng}$, Shayler paul, "Characterization of ignition delay period for a compression ignition engine operating on blended mixtures of diesel and gasoline", Applied Thermal Engineering, 66, 55 $-64,2014$.

20. Ozer Can, "Combustion characteristics, performance and exhaust emissions of a diesel engine fueled with a waste cooking oil biodiesel mixture", Energy Conversion Management, 87, $676-686,2014$.

21. Ekrem Buyukka, "Effects of biodiesel on a DI diesel engine performance, emission and combustion characteristics", Fuel, 89, 3099 3105, 2010.

22. Gums M, "A comprehensive experimental investigation of combustion and heat release characteristics of a biodiesel (hazelnut kernel oil methyl ester) fueled direct injection compression ignition engine", Fuel, 89, 2802-2814, 2010.

23. Xue J L, Grift T E, Hansen A C, "Effect 
of biodiesel on engine performance and emissions", Renewable and sustainable Energy Reviews, 15, 1098 - 1116, 2011.

24. Selman Aydin, Cenk Sayin, "Impact of thermal barrier application on the combustion, performance and emissions of a diesel engine fueled with waste cooking oil biodiesel-diesel blends", Fuel, 136, 334 - 340, 2014.

25. Canakci M, Van Gerpen J H, "Comparison of engine performance and emissions for petroleum diesel fuel, yellow grease biodiesel and soybean oil biodiesel", Trans ASAE, 46, 937 - 944, 2003.

26. Janun J, Ellis N, "Perspectives on biodiesel as a sustainable fuel", Renewable and sustainable Energy Reviews, 14, 1312 - 1320, 2010.

27. Ramadhas A S, Jayaraj S, Muraleedharan $\mathrm{C}$, "Performance and emission evaluation of a diesel fuelled with methyl esters of rubber seed oil", Renewable Energy, 30, 1789-1800, 2005.

28. Aydin $\mathrm{H}$, "Combined effects of thermal barrier coating and blending with diesel fuel on usability of vegetable oils in diesel engines", Applied Thermal Engineering, 51, 623 - 629, 2013.

29. Sayin C, Gumus M, Canakci M, "Influence of injector hole number on the performance and emission of a DI diesel engine fueled with biodiesel-diesel fuel blends", Applied Thermal Engineering, 61, 121 - 128, 2013.

30. Ozsezen A N, Canakci M, Turkan A, Sayin C, "Performance and combustion characteristics of a DI diesel engine fueled with waste palm oil and canola oil methyl esters", Fuel, 88, 629 - 636, 2009.

31. Anand K, Sharma R, Mehta P S, "Experimental investigation on combustion, performance and emissions characteristics of neat biodiesel and its methanol blend in a diesel engine", Biomass and Bioenergy, 35, 533 - 541, 2011.

32. Lin C, Lin S, "Effects of emulsification variables on fuel properties of two and three phase biodiesel emulsions", Fuel, 86, 210 - 217, 2007.

33. Venkata Ramanan M, Yuvarajan, "Emission analysis on the influence of magnetic nanofluid on methyl ester in diesel engine",
Atmospheric Pollution Research, 7:3, 477-481, 2016.

34. Dhinesh B, Niruban R, Bharathi, Isaac J, Joshua Ramesh Lalvani, Annamalai K, "An experimental analysis on the influence of fuel borne additives on the single cylinder diesel engine powered by Cymbopogon flexuosus biofuel", Journal of Energy Institute, 90, 634 645, 2017.

35. Muralidharan K, Vasudevan D, Sheeba $\mathrm{K} \mathrm{N}$, "Performance, emission and combustion characteristics of biodiesel fuelled variable compression ratio engine", Energy, 36, 53855393, 2011.

36. Varuvel E G, Mrad N, Tazerout M, Aloui F, "Experimental analysis of biofuel as an alternative fuel for diesel engines", Applied Energy, 94, $224-231,2012$. 